\title{
Virus Graph and COVID-19 Pandemic: A Graph Theory Approach
}

\author{
H. R. Bhapkar, Parikshit N. Mahalle, Prashant S. Dhotre ${ }^{3}$ \\ ${ }^{1}$ Department of Mathematics, MIT ADT University's, MIT School of \\ Enineering, Pune, Maharashtra, INDIA, hrbhapkar@gmail.com \\ ${ }^{2}$ Senior Member IEEE, Professor and Head, Department of Computer En- \\ gineering, STES'S, Smt. Kashibai Navale College of Engineering, Pune, \\ Maharashtra, INDIA, aalborg.pnm@gmail.com \\ ${ }^{3}$ Department of Information Technology, JSPM's Rajarshi Shahu College \\ of Engineering, Pune, Maharashtra, INDIA, prashantsdhotre@gmail.com
}

\begin{abstract}
Graph theory plays significant role in every field of science as well as technology. Every situation can be articulated in terms of suitable graphs by using various approaches of graph theory. Considering the recent pandemic in the world and the precautions taken for prevention of the COVID-19, it is the most appropriate way to exercise the graph models with theoretical as well as practical aspects to control this epidemic. This paper defines the variable set, variable graphs and their types with respect to variable vertex sets and variable edge sets. Depending upon the nature of the pandemic, there are four types of Virus graphs. Virus graph I and III are not so perilous for all living beings. Although, Virus graphs II and IV are extremely hazardous for the harmony of the world. In view of different aspects for expand of pandemic, growth types of virus graphs are divided in 1-1, 1-P and 1-all growth types. The COVID-19 initially was in Virus graph-I type, but presently it is in Virus graph-II types. We present the table involving the number of infected people after $\mathrm{n}$ days with respect to different values of $\mathrm{P}$ and growth rates with $\mathrm{I} 0=100$. Moreover, the country wise starting dates of stages of the virus graph-I and II are specified. The concept of cut sets is applicable for prevention of COVID-19 and the whole world is using the same analogy.
\end{abstract}


2 H. R. Bhapkar, Parikshit N. Mahalle, Prashant S. Dhotre

Keywords: virus graphs; COVID-19; pandemic; epidemic.

\subsection{Introduction}

COVID-19 is the transferrable disease caused by the recent coronavirus recently started in Wuhan, China. This virus and subsequently the disease were shadowy to the world before its outbreak. Considering the recent COVID-19 virus and its spread across globe, it is important to understand and visualize the virus spread and impact. The disease caused by this virus has become pandemic and many countries are affected badly. Using graph theory approach, this paper helps users to understand and visualize this disease, impact and spread. The different graph method presented in this paper shows virus, its growth type is presented using graph theory. The number of persons who are affected and prevention is also presented in this paper. The conclusion of this paper is that there is infinite scope of mathematics for the research as well resolving social problems like COVID-19 and technical problems.

The reader will refer [2], [5], [7], [21] for the absolute dealing with the subject matter. All Graphs considered in this paper are simple as well as connected. The neighbor of the vertex $\mathrm{v}$ in graph $\mathrm{H}$ is the set of all the vertices adjacent to the vertex $\mathrm{v}$ in $\mathrm{H}$. A graph with $\mathrm{n}$ vertices and without any edges is called the Null graph and it is denoted by Nn [2]. A simple connected graph, in which degree of each vertex is 2 , is called a cycle graph. $\mathrm{Cn}$ is the cycle graph on $\mathrm{n}$ vertices [21]. A graph, in which one vertex is adjacent to $\mathrm{n}$ pendent vertices, is called the star graph. It is symbolized by $\mathrm{K}_{1, \mathrm{n}}$. Here, $\left|\mathrm{V}\left(\mathrm{K}_{1, \mathrm{n}}\right)\right|=\mathrm{n}+1$ along with $\left|\mathrm{E}\left(\mathrm{K}_{1, \mathrm{n}}\right)\right|=\mathrm{n}[10]$.

The paper is organized as follows. Basic terms of graph are presented in Section 1.1. Motivation and related work is presented in section 1.2 and 1.3 respectively. Graphical theoretical model that emphasizes on Virus Graph I, II, III and IV is presented in section 1.4. Section 1.5 and 1.6 discusses on growth rate and its types. Country wise stages of Virus graph I and II is presented in section 1.7. Growth rate of COVID-19 is predicted and presented in section 1.8. This paper is summarized with future outlook in section 1.9. 


\subsubsection{Partite Graphs}

A graph $\mathrm{H}$ is n- partite graph if $\mathrm{V}(\mathrm{H})=\mathrm{V}_{1} \mathrm{U} \mathrm{V}_{2} \mathrm{U} \ldots$.., $U \mathrm{~V}_{\mathrm{n}}$, where all $\mathrm{V}_{\mathrm{i}}$ are disjoint and every edge of $H$ joins a vertex of $V_{i}$ and $V_{j}$ for $i \neq j$. If $n=$ 2, 3, 4 then graphs are called Bipartite, Tripartite and four partite respectively [2].

\subsubsection{Cut Sets}

A set of edges of a connected graph $\mathrm{H}$, whose removal disconnects $\mathrm{H}$, is called the disconnecting set of $\mathrm{H}$. The smallest disconnecting set is called the cut set of $\mathrm{H}[5],[21]$.

\subsubsection{Corona Product of Graphs}

The corona product of $\mathrm{H}$ and $\mathrm{K}$ is denoted by $\mathrm{H} \cdot \mathrm{K}$ and obtained from a copy of $H$ and $|V(H)|$ copies of $K$, joining each vertex of $H$ to all vertices of the graph K. This graph product was initiated by mathematicians Frucht and Harary in 1970 [1], [17].

\subsection{Motivation}

Almost 2.5 million cases of COVID-19 (corona virus) and more than 160,000 deaths have now been reported worldwide [21]. The largest part of the epidemic in the world comes into sight to be steady or declining [7]. A good number countries are immobile in the early stages of their epidemics and few of them were affected early in the pandemic are now starting to see an improvement in cases. Hence, it is the most important and essential to prevent the spread of such types of epidemic [10]. As we know, mathematical modelling award different astonishing inspiration and tools to study different communal as well as technical problems and interpret solutions. This will lead to find the practical solutions of a variety of problems and helps to continue the harmony of the mankind.

\subsection{Related Work}

Giulia Giordano et al [5] proposed an innovative epidemic model which distinguishes between infected people depending on whether they have been confirmed by considering their symptoms. Non diagnosed peoples can spread virus rapidly than diagnosed people. Therefore the divergence between diagnosed and non-diagnosed plays an important role for the deterrence of a pandemic. A fuzzy theory and deep learning networks help to 
enhance for acquiring superior stochastic insights concerning the epidemic growth is experimented [7]. A deep learning based Composite MonteCarlo (CMC) showed better results than simple Monte Carlo (MC) which will be obliged for decision makers for greater ranges of the future promises of epidemic and pandemic [3]. In paper [18], it is studied that due less and incorrect information about COVI-19, there is no any exact model which can predict spread of the pandemic. Every model has different levels of predictive efficiency.

By analyzing data in few countries, it is noted that an infection reached to peak around 10 days after the controlling measures are initiated. The growth rate of infected people was slowly decreasing during this period. But, especially the growth rate in Italy remains exponential. Hence, quarantine is insufficient and need strict measures [19]. In paper [20], the authors have made a mathematical model for the epidemic by applying linear differential equations. By identifying patterns and analyzing desired data, it is concluded that the growth rate is dynamic or exponential depending upon precautions taken by people. Shinde Gitanjali et al [9], presented and meticulously discussed different predictive analytic models as well as algorithms for the number infected cases in the near future. Moreover, the Prophet predictive analytics algorithm is implemented on the Kaggle dataset and its predictions are studied in their research work. The following new terms are defined for constructing the pedestal of mathematical modelling of any types of pandemic or COVID-19.

Critical decision making is difficult due to uncertainty caused by novel coronavirus epidemic. Fong et al [10] presented deep learning and fuzzy based prediction method for the future possibilities of coronavirus and its impact. The present events and its future behavior is presented using Composite Monte Carlo simulation method. The difficult task is accurate forecasting of destiny of an epidemic is presented by Fong et al [11] using augmentation of existing data, panel design for selection of best forecasting model and its fine tuning of parameters of each model. Deep learning method was presented by Hu et al [12] for forecasting of COVID-19.

Based on the lung CT scan images, Rajinikanth [13] presented a system for detection of COVID-19. This proposed method is based on Otsu and a meta-heuristic Harmony search algorithm. Using graph theory, data classification was proposed by Kamal [14] which is based on De-Bruijn graph with MapReduce framework.

After evaluation of related work, there is a need for the mathematical modelling and visualization of COVID-19 using graph theory is essential to spread awareness among many stakeholders. 


\subsubsection{Variable Set}

A set $\mathrm{S}$ is said to be Variable set if elements of the set $\mathrm{S}$ changes with respect to time or some rule. That is, the set $\mathrm{S}$ is not constant set. Its cardinality changes with respect to time. Sv is the notation of variable set. In the variable sets, time units depend upon its nature. According to the scenery of the cardinality of the set $\mathrm{S}$, there are three types of sets.

- Increasing Variable Set: A variable set $\mathrm{Sv}$ is said to be increasing variable set if $\left|S_{\mathrm{v}}(\mathrm{x})\right|<\left|S_{\mathrm{v}}(\mathrm{y})\right|$, whenever $\mathrm{x}<\mathrm{y}$, where $\mathrm{x}$ and $\mathrm{y}$ are different times.

- Decreasing Variable Set: A variable set $S_{\mathrm{v}}$ is said to be decreasing variable set if $\left|S_{\mathrm{v}}(\mathrm{x})\right|>\left|S_{\mathrm{v}}(\mathrm{y})\right|$, whenever $\mathrm{x}<\mathrm{y}$.

- Non Decreasing Variable Set: A variable set $S_{\mathrm{v}}$ is said to be nondecreasing variable set if $\left|S_{\mathrm{v}}(\mathrm{x})\right| \leq\left|\mathrm{S}_{\mathrm{v}}(\mathrm{y})\right|$, whenever $\mathrm{x} \leq \mathrm{y}$.

- Non Increasing Variable Set: A variable set $S_{\mathrm{v}}$ is said to be nonincreasing variable set if $\left|S_{\mathrm{v}}(\mathrm{x})\right| \geq\left|\mathrm{S}_{\mathrm{v}}(\mathrm{y})\right|$, whenever $\mathrm{x} \leq \mathrm{y}$.

- Stable Variable Set: A variable set $S_{\mathrm{v}}$ is said to be stable variable set if $\left|S_{v}(t)\right|=$ constant, for any time t. However, the set is a variable set. Elements of the set $S$ vary according to time, but the $\left|S_{v}(t)\right|$ is steady, for any time $t$.

\subsubsection{Variable Graph}

A graph $\mathrm{H}$ is said to be a vertex variable graph if $\mathrm{V}(\mathrm{H})$ or $\mathrm{E}(\mathrm{H})$ is variable sets. Variable graphs are also known as $\mathrm{V}$ - graphs. Big network graphs are variable graph. There are two types of variable graphs.

\subsubsection{Edge V-Graph}

A variable graph $\mathrm{H}$ is said to be edge $\mathrm{V}$ - graph if $\mathrm{E}(\mathrm{H})$ is a variable set and $\mathrm{V}(\mathrm{H})$ is the stable variable set.

\subsubsection{Vertex V-Graph}

A variable graph $\mathrm{H}$ is said to be vertex $\mathrm{V}$ - graph if $\mathrm{V}(\mathrm{H})$ is a variable set and $\mathrm{E}(\mathrm{H})$ is the constant variable set.

\subsection{5 n-partite V- Graphs}

A variable graph $\mathrm{H}$ is said to be n-partite $\mathrm{V}$ - Graph if

i. $\mathrm{V}(\mathrm{H})=\mathrm{V}_{1} \mathrm{U} \mathrm{V}_{2} \mathrm{U} \mathrm{V} \mathrm{V}_{3}, \ldots, \mathrm{V}_{\mathrm{n}}$ where $\mathrm{V}_{1}, \mathrm{~V}_{2}, \mathrm{~V}_{3}, \ldots, \mathrm{V}_{\mathrm{n}}$ disjoint variable sets having different characteristics.

ii. There exists a bond on the link or edge between vertices of Vi \& $\mathrm{Vj}$, for $\mathrm{i}, \mathrm{j}$ and $\mathrm{i} \neq \mathrm{j}$. 


\subsubsection{Bipartite V- Graph}

A variable graph $\mathrm{H}$ is said to be Bipartite $\mathrm{V}$ - Graph if

i. $\mathrm{V}(\mathrm{H})=\mathrm{V}_{1} \mathrm{U} \mathrm{V}_{2}$, where $\mathrm{V} 1$ and $\mathrm{V} 2$ are disjoint variable sets with different characteristics.

ii. There exists a bond on the link or edge between vertices of $V_{1}$ and vertices of $\mathrm{V}_{2}$

iii. There is no any bond among the vertices of $\mathrm{V}_{1}$ only or $\mathrm{V}_{2}$ only.

These types of graphs are denoted by $\mathrm{BV}_{2}$. In $\mathrm{BV}_{2}$, a vertex $\mathrm{x}$ of $\mathrm{V}_{1}$ is said to be Active Vertex or element if there exists a bond between $\mathrm{x}$ and at least one vertex of $\mathrm{V}_{2}$ or $\mathrm{x}$ is trying to build a bond or edges to the vertices of $\mathrm{V}_{2}$. Moreover, $\mathrm{x}$ is ready for the sharing some characteristics. Other vertices of $V_{1}$ are known as the Passive Vertices. A vertex $y$ of $V_{2}$ is said to be Active Vertex or element if there exists a bond between y and at least one vertex of $\mathrm{V}_{1}$ or $\mathrm{y}$ is aiming to build a bond or edges to the vertices of $\mathrm{V}_{1}$. Other vertices of $\mathrm{V}_{2}$ are known as the Passive Vertices.

\subsection{Graph Theoretical Model}

\subsubsection{Virus Graph I}

A Bipartite V-graph H is said to be Virus Graph I (VRG-I) if

i. $V(H)=I U N$, where, I be the variable set of vertices have some special properties or infected by virus and $\mathrm{N}$ be the variable set of vertices not having a virus.

ii. If $x \in I$, creates a bond or an edge with the vertex $y \in N$ or vice versa, then $y$ is shifted to $I$ and $N=N-\{y\}$.

iii. If $x \in I$, is recovered by treatment or lost properties of virus then, $x$ is shifted to $\mathrm{N}$ and $\mathrm{N}=\mathrm{NU}\{\mathrm{x}\}$. The diagrammatic representation of VRG-I is shown in fig.4.1.

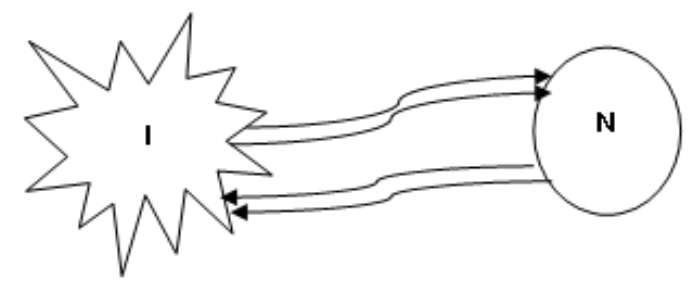

Fig.4.1 Virus Graph I 


\subsubsection{Virus Graph II}

A Tripartite V-graph H is said to be Virus Graph II (VRG-II) if

i. $\quad \mathrm{V}(\mathrm{H})=\mathrm{I} U \mathrm{~N} U \mathrm{~F}$, where, I be the variable set of vertices having the virus, $\mathrm{N}$ be the variable set of vertices not having virus and $\mathrm{F}$ be the set of vertices which can never be shifted to I or N.

ii. If $x \in I$, creates a bond or an edge with the vertex $y \in N$ or vice versa, then $\mathrm{y}$ is shifted to $\mathrm{I}$ and $\mathrm{N}=\mathrm{N}-\{\mathrm{y}\}$.

iii. If $x \in I$, is recovered by treatment or vanished properties of virus then, $\mathrm{x}$ is shifted to $\mathrm{N}$ and $\mathrm{N}=\mathrm{NU}\{\mathrm{x}\}$.

iv. Vertices of $I$ are shifted to $F$ if the vertices are infected forever. Therefore, $\mathrm{S}$ is the non-decreasing variable set. This is represented in Fig.4.2

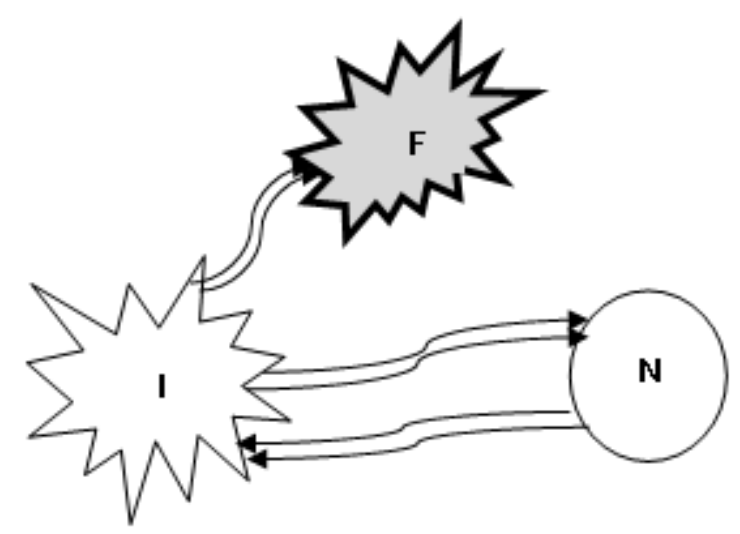

Fig.4.2 Virus Graph II

\subsubsection{Virus Graph III}

A Tripartite V-graph H is said to be Virus Graph III (VRG-III) if

i. $\mathrm{V}(\mathrm{H})=\mathrm{I} U \mathrm{U} U \mathrm{~S}$, where, $\mathrm{S}$ be the set of vertices which is never infected by the virus.

ii. If $x \in I$, creates a bond or an edge with the vertex $y \in N$ or vice versa, then $y$ is shifted to $I$ and $N=N-\{y\}$.

iii. If $x \in I$, is recovered by treatment or lost properties of virus then, $\mathrm{x}$ is shifted to $\mathrm{N}$ and $\mathrm{N}=\mathrm{NU}\{\mathrm{x}\}$.

iv. Vertices of N, with some additional features, can be shifted to variable set $\mathrm{S}$. Furthermore, the vertices of $\mathrm{S}$ are protected by a shield of antivirus or some special vaccines. The vertices of V can't be directly transformed into $\mathrm{S}$, but transformed to $\mathrm{N}$ and $\mathrm{N}$ to $\mathrm{S}$. Con- 
8 H. R. Bhapkar, Parikshit N. Mahalle, Prashant S. Dhotre

sequently, $\mathrm{S}$ is the non-decreasing variable set. This occurrence is shown in fig 4.3.

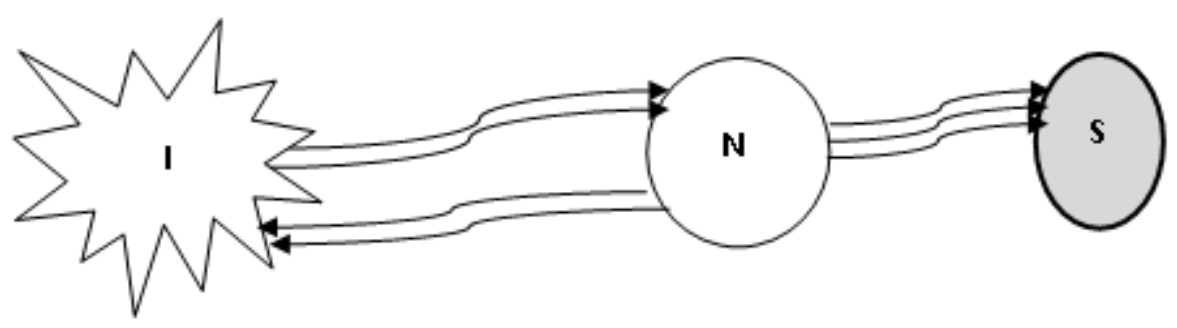

Fig.4.3 Virus Graph III

\subsubsection{Virus Graph IV}

A four partite V-graph $\mathrm{H}$ is said to be Virus Graph IV (VRG-IV) if

i. $\mathrm{V}(\mathrm{H})=\mathrm{I} U \mathrm{~N} \mathrm{US} \mathrm{U} \mathrm{F}$, where, F be the set of vertices which can never be shifted to I or $\mathrm{N}$ or $\mathrm{S}$.

ii. If $x \in I$, creates a bond or an edge with the vertex $y \in N$ or vice versa, then $\mathrm{y}$ is shifted to $\mathrm{I}$ and $\mathrm{N}=\mathrm{N}-\{\mathrm{y}\}$.

iii. If $x \in I$, is recovered by treatment or lost properties of virus then, $\mathrm{x}$ is shifted to $\mathrm{N}$ and $\mathrm{N}=\mathrm{NU}\{\mathrm{x}\}$.

iv. Vertices of $\mathrm{N}$, with some additional features, can be shifted to variable set $\mathrm{S}$. Furthermore, the vertices of $\mathrm{S}$ are protected by a shield of antivirus or some special vaccines.

Vertices of $\mathrm{F}$ can be never shifted to any other set. The elements of $\mathrm{F}$ are having philosophy "infected once is infected forever". It is shown in fig. 4.4

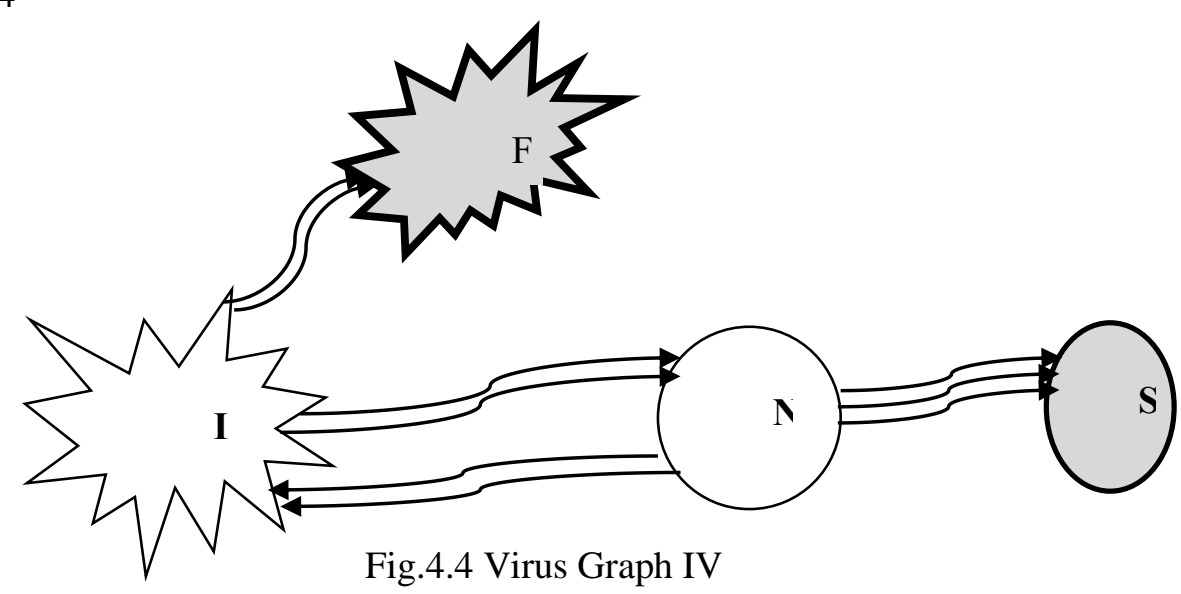

Fig.4.4 Virus Graph IV 
Virus Graph and COVID-19 Pandemic: A Graph Theory Approach 9

Virus Graph: A variable graph is said to be a Virus graph if it belongs to class of either Virus graph-I or Virus graph-II or Virus graph-III or Virus graph-IV.

\subsection{Growth Rate}

The growth rate of any V-graph is the rate of increase of active elements minus the rate of increase of passive elements.

\subsection{Types of growth}

There are three types of growth of any virus, according to graph theory.

\subsubsection{One - One Growth:}

A growth is said to be one - one or 1-1 growth if one active element of the variable set infects only one active element of another set at that instant. This growth is articulated as the corona product of cycle graph with $\mathrm{K}_{1}$. Here $\mathrm{Cm}$ is the cycle graph having $\mathrm{r}$ active elements, which are elements of the variable set I. Additionally, $\mathrm{K}_{1}$ is an individual active element of the variable set N. It is shown in Fig. 4.5

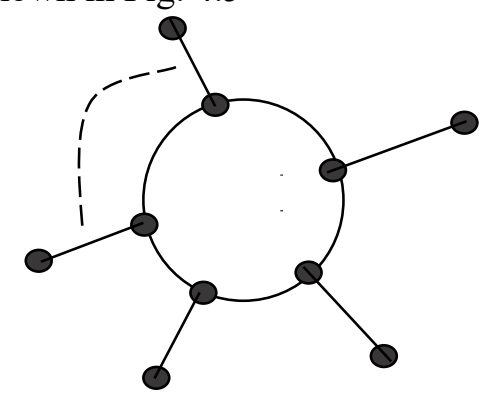

Fig. 4.5 One - One Growth

\section{- Growth rate is constant}

Without loss of generality, assume that there are $30 \%$ active elements in each set. Also assume that the number of infected people is extremely less than the total population. In this growth type, every day $30 \%$ new patients are increased in the set $\mathrm{I}$. Let $\mathrm{I}_{0}$ be the number of people infected by the virus at initial stage. Let In be the number of people will be infected after $n$ days. As a result, 
10 H. R. Bhapkar, Parikshit N. Mahalle, Prashant S. Dhotre

$$
\begin{aligned}
& \mathrm{I}_{1}=\mathrm{I}_{0}+(0.30) \mathrm{I}_{0}=1.3 * \mathrm{I}_{0}, \\
& \mathrm{I}_{2}=\mathrm{I}_{1}+(0.30) \mathrm{I}_{1}=1.30^{*} \mathrm{I}_{1}=1.3\left(1.3 * \mathrm{I}_{0}\right)=(1.3)^{2} \mathrm{I}_{0}
\end{aligned}
$$

In general, $\mathrm{I}_{\mathrm{n}}=(1.3)^{\mathrm{n}} * \mathrm{I}_{0}$.

Let $\mathrm{R}$ be the rate of the virus per unit tine and $\mathrm{I}_{0}$ be an initial number of infected people. Therefore,

$$
\mathrm{I}_{1}=\mathrm{I}_{0}+\mathrm{R} \mathrm{I}_{0}=(1+\mathrm{R}) \mathrm{I}_{0},
$$

After second time interval,

$$
\mathrm{I}_{2}=\mathrm{I}_{1}+\mathrm{R} \mathrm{I}_{1}=(1+\mathrm{R}) \mathrm{I}_{1}=(1+\mathrm{R})^{2} \mathrm{I}_{0} .
$$

After $n$ time intervals, the number of infected people will be

$$
I_{n}=(1+R)^{n} I_{0}
$$

\section{- Growth rate is not constant}

Now, assume that the growth rate is different in each time interval as given table 1.1

Table 1.1. Growth rate and time interval

\begin{tabular}{llllllll}
\hline $\begin{array}{l}\text { After } \\
\text { Time ti }\end{array}$ & $\mathrm{t} 1$ & $\mathrm{t} 2$ & $\mathrm{t} 3$ & $\mathrm{t} 4$ & $\ldots$ & $\mathrm{tn}-1$ & $\mathrm{tn}$ \\
\hline $\begin{array}{l}\text { Growth } \\
\text { Rate Ri }\end{array}$ & $\mathrm{R} 1$ & $\mathrm{R} 2$ & $\mathrm{R} 3$ & $\mathrm{R} 4$ & $\ldots$ & $\mathrm{Rn}-1$ & $\mathrm{Rn}$ \\
\hline
\end{tabular}

After the second time interval,

$$
\begin{aligned}
& I_{2}=I_{1}+R_{2} I_{1}=\left(1+R_{2}\right) I_{1}=\left(1+R_{2}\right)\left(1+R_{1}\right) I_{0}, \\
& I_{3}=\left(1+R_{3}\right)\left(1+R_{2}\right)\left(1+R_{1}\right) I_{0},
\end{aligned}
$$

After $n$ time intervals, the number of infected people is

$$
I_{n}=\left(1+R_{n}\right) \ldots\left(1+R_{2}\right)\left(1+R_{1}\right) I_{0} .
$$

Moreover, at time $t_{i}$, growth rate is $R_{i}$ and $R_{i}$ is repeated $m_{i}$ times in the given interval. Hence,

$$
\begin{gathered}
I_{n}=\left(1+R_{1}\right)^{m_{1}}\left(1+R_{2}\right)^{m_{2}} \Lambda \quad\left(1+R_{j}\right)^{m_{j}} \\
\text { where } 1 \leq \mathrm{j} \leq \mathrm{n} \text { and } \mathrm{m}_{1}+\mathrm{m}_{2}+\ldots+\mathrm{m}_{\mathrm{j}}=\mathrm{n} .
\end{gathered}
$$


Virus Graph and COVID-19 Pandemic: A Graph Theory Approach 11

Thus, the growth of the infected people is exponential. Consider the table 1.2 for the number of elements in I after nth days corresponding to various percentages of active elements with $\mathrm{I}_{0}=100$.

Table 1.2. Number of elements in I after $n^{\text {th }}$ days with respect to active elements

\begin{tabular}{|c|c|c|c|c|c|c|c|c|c|c|}
\hline $\begin{array}{c}\text { No } \\
\text {. of } \\
\text { days }\end{array}$ & $\begin{array}{c}\text { In } \\
\text { (Growth } \\
30 \% \text { ) }\end{array}$ & $\begin{array}{c}\text { In } \\
\text { (Growth } \\
1 \%)\end{array}$ & $\begin{array}{c}\text { In } \\
\text { (Growth } \\
2 \% \text { ) }\end{array}$ & $\begin{array}{c}\text { I } \\
n \\
\text { (Gro ( } \\
\text { wth } \\
3 \%)\end{array}$ & $\begin{array}{l}\text { In } \\
\text { irowth } \\
4 \%( \\
)^{4}\end{array}$ & $\begin{array}{c}\text { In } \\
\text { (Growth } \\
5 \% \text { ) }\end{array}$ & $\begin{array}{c}\text { In } \\
\text { (Growth } \\
7 \%)\end{array}$ & $\begin{array}{c}\text { In } \\
\text { (Growth } \\
10 \% \\
\text { ) }\end{array}$ & $\begin{array}{c}\text { In } \\
\text { (Growth } \\
15 \% \text { ) }\end{array}$ & $\begin{array}{c}\text { In } \\
\text { ( Growth } \\
20 \% \text { ) }\end{array}$ \\
\hline & & & & 1 & & & & & & \\
\hline 1 & 130 & 101 & 102 & $\begin{array}{l}03 \\
1\end{array}$ & 104 & 105 & 107 & 110 & 115 & 120 \\
\hline 2 & 169 & 102 & 104 & $\begin{array}{l}06 \\
1\end{array}$ & 108 & 110 & 114 & 121 & 132 & 144 \\
\hline 3 & 220 & 103 & 106 & $\begin{array}{l}09 \\
1\end{array}$ & 112 & 116 & 123 & 133 & 152 & 173 \\
\hline 4 & 286 & 104 & 108 & $\begin{array}{l}13 \\
1\end{array}$ & 117 & 122 & 131 & 146 & 175 & 207 \\
\hline 5 & 371 & 105 & 110 & $\begin{array}{l}16 \\
1\end{array}$ & 122 & 128 & 140 & 161 & 201 & 249 \\
\hline 6 & 483 & 106 & 113 & $\begin{array}{l}19 \\
1\end{array}$ & 127 & 134 & 150 & 177 & 231 & 299 \\
\hline 7 & 627 & 107 & 115 & $\begin{array}{l}23 \\
1\end{array}$ & 132 & 141 & 161 & 195 & 266 & 358 \\
\hline 8 & 816 & 108 & 117 & $\begin{array}{l}27 \\
1\end{array}$ & 137 & 148 & 172 & 214 & 306 & 430 \\
\hline 9 & 1060 & 109 & 120 & $\begin{array}{r}30 \\
1\end{array}$ & 142 & 155 & 184 & 236 & 352 & 516 \\
\hline 10 & 1379 & 110 & 122 & $\begin{array}{r}34 \\
1\end{array}$ & 148 & 163 & 197 & 259 & 405 & 619 \\
\hline 15 & 5119 & 116 & 135 & $\begin{array}{r}56 \\
1\end{array}$ & 180 & 208 & 276 & 418 & 814 & 1541 \\
\hline 20 & 19005 & 122 & 149 & $\begin{array}{l}81 \\
2\end{array}$ & 219 & 265 & 387 & 673 & 1637 & 3834 \\
\hline 25 & 70564 & 128 & 164 & $\begin{array}{l}09 \\
2\end{array}$ & 267 & 339 & 543 & 1083 & 3292 & 9540 \\
\hline 30 & 262000 & 135 & 181 & $\begin{array}{l}43 \\
2\end{array}$ & 324 & 432 & $\begin{array}{l}761 \\
106\end{array}$ & 1745 & 6621 & 23738 \\
\hline 35 & 972786 & 142 & 200 & $\begin{array}{l}81 \\
3\end{array}$ & 395 & 552 & $\begin{array}{l}8 \\
149\end{array}$ & 2810 & 13318 & 59067 \\
\hline 40 & 3611886 & 149 & 221 & $\begin{array}{r}26 \\
4\end{array}$ & 480 & $\begin{array}{l}704 \\
114\end{array}$ & $\begin{array}{l}7 \\
294\end{array}$ & $\begin{array}{l}4526 \\
1173\end{array}$ & 26786 & 146977 \\
\hline 50 & 49792922 & 164 & 269 & $\begin{array}{r}38 \\
5\end{array}$ & $\begin{array}{l}711 \\
105\end{array}$ & $\begin{array}{l}7 \\
186\end{array}$ & $\begin{array}{l}6 \\
579\end{array}$ & $\begin{array}{l}9 \\
3044\end{array}$ & 108366 & 910044 \\
\hline 60 & 686437717 & 182 & 328 & $\begin{array}{l}89 \\
7\end{array}$ & $\begin{array}{l}2 \\
155\end{array}$ & $\begin{array}{l}8 \\
304\end{array}$ & $\begin{array}{l}5 \\
113\end{array}$ & $\begin{array}{l}8 \\
7897\end{array}$ & 438400 & 5634751 \\
\hline 70 & $\begin{array}{c}9463126845 \\
13045723950\end{array}$ & 201 & 400 & $\begin{array}{r}92 \\
1\end{array}$ & $\begin{array}{l}7 \\
230\end{array}$ & $\begin{array}{l}3 \\
495\end{array}$ & $\begin{array}{l}99 \\
224\end{array}$ & $\begin{array}{l}5 \\
2048\end{array}$ & 1773572 & 34888896 \\
\hline 80 & $\begin{array}{c}5 \\
17984638288\end{array}$ & 222 & 488 & $\begin{array}{r}064 \\
1\end{array}$ & $\begin{array}{l}5 \\
341\end{array}$ & $\begin{array}{l}6 \\
807\end{array}$ & $\begin{array}{l}23 \\
441\end{array}$ & $\begin{array}{l}40 \\
5313\end{array}$ & $\begin{array}{l}7175088 \\
2902723\end{array}$ & $\begin{array}{l}216022846 \\
133755652\end{array}$ \\
\hline 90 & 96 & 245 & 594 & 430 & 2 & 3 & 10 & 02 & 3 & 5 \\
\hline 100 & 24793351109 & 270 & 724 & 1 & 505 & 131 & 867 & 1378 & 1174313 & 828179745 \\
\hline
\end{tabular}


12 H. R. Bhapkar, Parikshit N. Mahalle, Prashant S. Dhotre

\begin{tabular}{|c|c|c|c|c|c|c|c|c|c|}
\hline & 660 & & 922 & 0 & 50 & 72 & 061 & 45 & 2 \\
\hline 120 & $\begin{array}{c}47119673969 \\
69860\end{array}$ & 330 & $\begin{array}{r}3 \\
1077471\end{array}$ & $\begin{array}{l}110 \\
66\end{array}$ & $\begin{array}{l}348 \\
91\end{array}$ & $\begin{array}{l}335 \\
779\end{array}$ & $\begin{array}{l}9270 \\
907\end{array}$ & $\begin{array}{l}1921944 \\
500\end{array}$ & $\begin{array}{c}317504237 \\
378\end{array}$ \\
\hline
\end{tabular}

In this growth type, by table 4.2 , it seems that if growth rate is $30 \%$, then the number of infected people will reach to 1060 after $9^{\text {th }}$ day, 19005 after the 20th day, 262000 after the 30th day and 24793351109660 after $100^{\text {th }}$ day. But if growth rates are $1 \%, 2 \%, 3 \%, 4 \%$ and $5 \%$, then the number of infected people will be 245, 594, 1430, 3412 and 8073 respectively after $100^{\text {th }}$ days. Therefore, the growth rate of any pandemic must be very less for the welfare of mankind.

\subsubsection{One - P Growth}

If one active element of the variable set (I) infects at most $p$ active elements of another set $(\mathrm{N})$ together at that instant, is called One $-\mathrm{P}$ growth or 1-P growth. In this case, $\mathrm{Cm}$ is the cycle graph having $\mathrm{r}$ active elements of variable set I and there is a group of $\mathrm{P}$ individual active elements of variable set $\mathrm{N}$. Therefore, it is the corona product of the $\mathrm{Cm}$ with null graph having $\mathrm{n}$ vertices, which is shown in fig. 4.6.

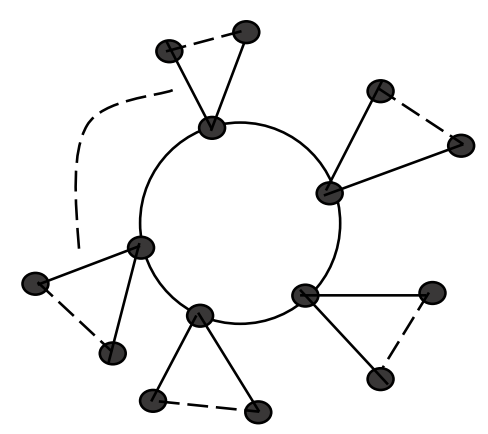

Fig. 4.6 One - P Growth

Without loss of generality, assume that there are $\mathrm{R}$ active elements in each set. R \% new patients are increased every day in the set I. Let I0 be the number of people infected by the virus at initial stage. Let In be the number of people will be infected after $n$ days.

As a result,

$$
\begin{aligned}
& \mathrm{I}_{1}=\mathrm{I}_{0}+(\mathrm{R} * \mathrm{P}) \mathrm{I}_{0}=(1+\mathrm{R} * \mathrm{P}) * \mathrm{I}_{0}, \\
& \mathrm{I}_{2}=\mathrm{I}_{1}+(\mathrm{R} * \mathrm{P}) \mathrm{I}_{1}=(1+\mathrm{R} * \mathrm{P})^{2} * \mathrm{I}_{0}=(1.3)^{2} \mathrm{I}_{0}
\end{aligned}
$$

In general,

$$
\mathrm{I}_{\mathrm{n}}=(1+\mathrm{R} * \mathrm{P})^{\mathrm{n}} * \mathrm{I}_{0}
$$


The number of infected people will be doubled in at most in Error! Bookmark not defined. days.

If $R=0.01$ and $n=2$, then the greatest value of $P$ is the value where $I_{0}$ will become doubled. Therefore, The greatest value of $\mathrm{P}$ is $\left(e^{0.34657}-1\right) * 100 \approx 42$. Hence, growth is $1-\mathrm{P}$ type if the value of $\mathrm{P} \leq 42$.

For the greater values of $\mathrm{P}$, the growth type is 1 - all growth.

\subsubsection{One - All Growth}

If one active element of the variable set infects all or more than 42 active elements of another set together at that instant, is called 1 - all growth. Such types of growth occur through water or air only. This is extremely perilous for living beings. $\mathrm{Cm}$ is the cycle graph having $\mathrm{r}$ active elements of variable set I and the group of the active elements of the variable set $\mathrm{N}$. This is the corona product of $\mathrm{Cm}$ with all individual elements of null graph having more than 42 vertices. Its graph is given in fig. 4.7.

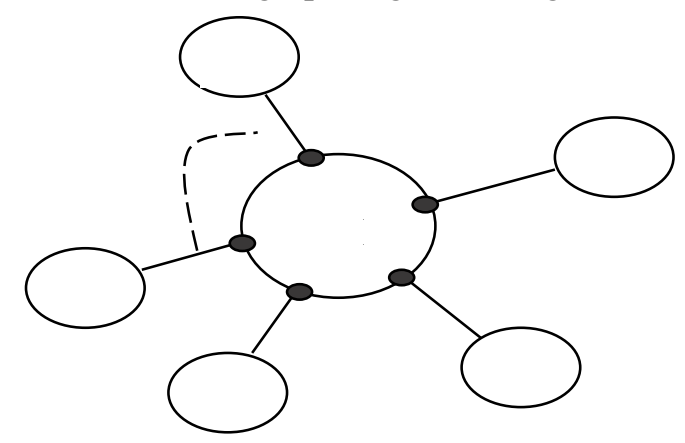

Fig. 4.7 One - All Growth

\subsection{COVID-19}

COVID-19 is a virus graph. At the initial stage, it was in the type virus graph-I. Let V (C) and E (C) are the variable vertex set (the set of people) and variable edge set of the COVID-19 graph C. Therefore, V(C) $=$ I U N, where I be the variable set of people infected by the virus COVID-19 and $\mathrm{N}$ be the variable set of people not infected by the COVID-19. Some corona viruses can be transmitted from person to person, generally after close contact with an infected patient, for example, in a household workplace, or health care center. 
The continuity of the graph $\mathrm{C}$ can be disconnected by the disconnecting set. So, keep all vertices of either set in the disconnecting set.

That is

$$
\mathrm{D}=\{\mathrm{I}\} \text { or } \mathrm{D}=\{\mathrm{N}\}
$$

Moreover, the cut set of $\mathrm{C}$ is $\{\mathrm{I}\}$ if $|\mathrm{I}| \leq|\mathrm{N}|$, otherwise, the cut set is $\{\mathrm{N}\}$. At present, every country of the world is doing the same for controlling the effect of COVID-19. We isolate people of set I as well as $\mathrm{N}$ or quarantine the people of set I or N, as per the necessities.

Presently, COVID-19 is in the virus graph-II type. Moreover,

$$
\mathrm{V}(\mathrm{C})=\mathrm{I} \text { U N U F }
$$

where $\mathrm{F}$ be the set of people, who are infected permanently. The people of the set $\mathrm{F}$ will not be recovered by any medicine and will die in the near future. The whole world is suffering from the effect of this virus and everyone is fervently waiting for the vaccine of this virus.

The table 1.3 gives the country wise starting dates of stages of the virus graph-I and II.

Table 1.3. Country wise stages of the virus graph-I and II.

\begin{tabular}{llll}
\hline Sr. No. & $\begin{array}{l}\text { Name of } \\
\text { Country }\end{array}$ & $\begin{array}{l}\text { Virus Graph- I } \\
\text { from }\end{array}$ & $\begin{array}{l}\text { Virus Graph- II } \\
\text { from }\end{array}$ \\
\hline 1 & Afghanistan & $\begin{array}{l}\text { 25-Feb-20 } \\
\text { 15-Feb-20 }\end{array}$ & $\begin{array}{l}\text { 24-Mar-20 } \\
\text { 9-Mar-20 }\end{array}$ \\
2 & Africa & 25-Jan-20 & 1-Mar-20 \\
3 & Australia & 20-Mar-20 & 9-Apr-20 \\
4 & Bermuda & 6-Mar-20 & - \\
5 & Bhutan & 12-Mar-20 & 1-Apr-20 \\
6 & Bolivia & 26-Feb-20 & 18-Mar-20 \\
7 & Brazil & 8-Mar-20 & 12-Mar-20 \\
8 & Bulgaria & 28-Jan-20 & - \\
9 & Cambodia & 26-Jan-20 & 10-Mar-20 \\
10 & Canada & 31-Dec-19 & 11-Jan-20 \\
11 & China & 7-Mar-20 & 22-Mar-20 \\
12 & Colombia & 27-Feb-20 & 16-Mar-20 \\
13 & Denmark & 15-Feb-20 & 9-Mar-20 \\
14 & Egypt & 25-Jan-20 & 15-Feb-20 \\
15 & Europe & 30-Jan-20 & 22-Mar-20 \\
16 & Finland & 25-Jan-20 & 15-Feb-20 \\
17 & France & & \\
\hline
\end{tabular}


Virus Graph and COVID-19 Pandemic: A Graph Theory Approach 15

\begin{tabular}{|c|c|c|c|}
\hline 18 & Germany & 28-Jan-20 & 12-Mar-20 \\
\hline 19 & Ghana & 13-Mar-20 & 22-Mar-20 \\
\hline 20 & Greece & $27-F e b-20$ & 12-Mar-20 \\
\hline 21 & Greenland & 20-Mar-20 & - \\
\hline 22 & Hungary & 5-Mar-20 & 16-Mar-20 \\
\hline 23 & India & 30-Jan-20 & 13-Mar-20 \\
\hline 24 & Indonesia & 2-Mar-20 & 12-Mar-20 \\
\hline 25 & Iran & $20-F e b-20$ & $23-F e b-20$ \\
\hline 26 & Iraq & 25-Feb-20 & 14-Mar-20 \\
\hline 27 & Ireland & 1-Mar-20 & 12-Mar-20 \\
\hline 28 & Israel & $22-F e b-20$ & 21-Mar-20 \\
\hline 29 & Italy & 31-Jan-20 & 27-Feb-20 \\
\hline 30 & Japan & 15-Jan-20 & $13-\mathrm{Feb}-20$ \\
\hline 31 & Kenya & 14-Mar-20 & 27-Mar-20 \\
\hline 32 & Kuwait & 24-Feb-20 & 5-Apr-20 \\
\hline 33 & Malaysia & 25-Jan-20 & 25-Mar-20 \\
\hline 34 & Nepal & 25-Jan-20 & - \\
\hline 35 & Netherlands & 28-Feb-20 & 7-Mar-20 \\
\hline 36 & New Zealand & $28-F e b-20$ & 29-Mar-20 \\
\hline 37 & $\begin{array}{l}\text { North } \\
\text { America }\end{array}$ & 21-Jan-20 & 1-Mar-20 \\
\hline 38 & Oman & $25-F e b-20$ & 1-Apr-20 \\
\hline 39 & Pakistan & $27-F e b-20$ & 21-Mar-20 \\
\hline 40 & Peru & 7-Mar-20 & 21-Mar-20 \\
\hline 41 & Poland & 4-Mar-20 & 13-Mar-20 \\
\hline 42 & Russia & 1-Feb-20 & 29-Mar-20 \\
\hline 43 & Rwanda & 15-Mar-20 & - \\
\hline 44 & Singapore & 24-Jan-20 & 29-Mar-20 \\
\hline 45 & South Africa & 6-Mar-20 & 31-Mar-20 \\
\hline 46 & South America & $26-F e b-20$ & 8-Mar-20 \\
\hline 47 & South Korea & 20-Jan-20 & 21-Feb-20 \\
\hline 48 & South Sudan & 6-Apr-20 & - \\
\hline 49 & Spain & 1-Feb-20 & 5-Mar-20 \\
\hline 50 & Sri Lanka & 28-Jan-20 & 29-Mar-20 \\
\hline 51 & Sudan & 14-Mar-20 & 15-Mar-20 \\
\hline 52 & Swaziland & 15-Mar-20 & 18-Apr-20 \\
\hline 53 & Sweden & 1-Feb-20 & 12-Mar-20 \\
\hline 54 & Switzerland & $26-F e b-20$ & 6-Mar-20 \\
\hline 55 & Taiwan & 21-Jan-20 & $17-F e b-20$ \\
\hline 56 & Thailand & 13-Jan-20 & 1-Mar-20 \\
\hline
\end{tabular}


16 H. R. Bhapkar, Parikshit N. Mahalle, Prashant S. Dhotre

\begin{tabular}{llll}
\hline & & & \\
\hline 57 & Turkey & 12-Mar-20 & 19-Mar-20 \\
58 & Uganda & 22-Mar-20 & - \\
59 & United Arab Emirates & 27-Jan-20 & 1-Apr-20 \\
60 & United Kingdom & 31-Jan-20 & 6-Mar-20 \\
61 & United States & 21-Jan-20 & 1-Mar-20 \\
62 & Vietnam & 24-Jan-20 & - \\
63 & Yemen & 10-Apr-20 & - \\
64 & Zimbabwe & 21-Mar-20 & 24-Mar-20 \\
\hline
\end{tabular}

It is observed that if we take desired precautions, then we can control the spread of the epidemic or pandemic. There are few countries still in virus graph-I and most of the countries rapidly reached to virus graph-II.

After discovering the vaccine on COVID-19, it will be shifted to virus graph-IV type. Therefore,

$$
\mathrm{V}(\mathrm{C})=\mathrm{I} U \mathrm{~N} \mathrm{U} \mathrm{F} \text { U S, }
$$

where $S$ be the set of vertices which can never be infected by virus. That is all people in the set $\mathrm{S}$ are vaccinated by desired medicines.

In this situation, we need to increase the number of elements of the set $S$ up to the whole population of the universal set. Hence, everyone will be free from the effect of the virus.

Moreover, hope that there should not be such types of pandemic, but if so, that must be Virus graph-III. This will help to preserve excellent harmony of living beings.

\subsection{Growth rate of COVID-19}

The growth type of the COVID-19 is 1- P growth. One person can infect at most $\mathrm{P} \leq 42$ persons at a time. For the superior values of $\mathrm{P}$, this growth is also called Small Community Spread.

The table 1.3 gives the number of infected people after $\mathrm{n}$ days with respect to different values of $\mathrm{P}$ and growth rates with $\mathrm{I}_{0}=100$.

Table 1.3. Number of infected people with respect to $R$ and $P$

\begin{tabular}{|c|c|c|c|c|c|c|c|c|c|c|}
\hline \multirow[t]{2}{*}{$\begin{array}{l}\text { Patien } \\
\text { no. }\end{array}$} & \multicolumn{2}{|c|}{$\begin{array}{c}\mathrm{I}_{\mathrm{n}} \\
\text { Growth } \\
\text { Rate } 1 \%\end{array}$} & \multicolumn{2}{|c|}{$\begin{array}{c}\mathrm{I}_{\mathrm{n}} \\
\text { Growth } \\
\text { Rate 2\% }\end{array}$} & \multicolumn{2}{|c|}{$\begin{array}{c}I_{n} \\
\text { Growth } \\
\text { Rate 3\% }\end{array}$} & \multicolumn{2}{|c|}{$\begin{array}{c}\mathrm{I}_{\mathrm{n}} \\
\text { Growth Rate } \\
4 \%\end{array}$} & \multicolumn{2}{|c|}{$\begin{array}{c}\mathrm{I}_{\mathrm{n}} \\
\text { Growth Rate } \\
5 \%\end{array}$} \\
\hline & $\mathrm{P}=3$ & $\mathrm{P}=5$ & $\mathrm{P}=3$ & $\mathrm{P}=5$ & $\mathrm{P}=3$ & $P=5$ & $\mathrm{P}=3$ & $\mathrm{P}=5$ & $\mathrm{P}=3$ & $\mathrm{P}=5$ \\
\hline
\end{tabular}


Virus Graph and COVID-19 Pandemic: A Graph Theory Approach 17

\begin{tabular}{|c|c|c|c|c|c|c|c|c|c|c|}
\hline 1 & 103 & 105 & 106 & 110 & 109 & 115 & 112 & 120 & 115 & 125 \\
\hline 2 & 106 & 110 & 112 & 121 & 119 & 132 & 125 & 144 & 132 & 156 \\
\hline 3 & 109 & 116 & 119 & 133 & 130 & 152 & 140 & 173 & 152 & 195 \\
\hline 4 & 113 & 122 & 126 & 146 & 141 & 175 & 157 & 207 & 175 & 244 \\
\hline 5 & 116 & 128 & 134 & 161 & 154 & 201 & 176 & 249 & 201 & 305 \\
\hline 6 & 119 & 134 & 142 & 177 & 168 & 231 & 197 & 299 & 231 & 381 \\
\hline 7 & 123 & 141 & 150 & 195 & 183 & 266 & 221 & 358 & 266 & 477 \\
\hline 8 & 127 & 148 & 159 & 214 & 199 & 306 & 248 & 430 & 306 & 596 \\
\hline 9 & 130 & 155 & 169 & 236 & 217 & 352 & 277 & 516 & 352 & 745 \\
\hline 10 & 134 & 163 & 179 & 259 & 237 & 405 & 311 & 619 & 405 & 931 \\
\hline 11 & 138 & 171 & 190 & 285 & 258 & 465 & 348 & 743 & 465 & 1164 \\
\hline 12 & 143 & 180 & 201 & 314 & 281 & 535 & 390 & 892 & 535 & 1455 \\
\hline 13 & 147 & 189 & 213 & 345 & 307 & 615 & 436 & 1070 & 615 & 1819 \\
\hline 14 & 151 & 198 & 226 & 380 & 334 & 708 & 489 & 1284 & 708 & 2274 \\
\hline 15 & 156 & 208 & 240 & 418 & 364 & 814 & 547 & 1541 & 814 & 2842 \\
\hline 16 & 160 & 218 & 254 & 459 & 397 & 936 & 613 & 1849 & 936 & 3553 \\
\hline 17 & 165 & 229 & 269 & 505 & 433 & 1076 & 687 & 2219 & 1076 & 4441 \\
\hline 18 & 170 & 241 & 285 & 556 & 472 & 1238 & 769 & 2662 & 1238 & 5551 \\
\hline 19 & 175 & 253 & 303 & 612 & 514 & 1423 & 861 & 3195 & 1423 & 6939 \\
\hline 20 & 181 & 265 & 321 & 673 & 560 & 1637 & 965 & 3834 & 1637 & 8674 \\
\hline 21 & 186 & 279 & 340 & 740 & 611 & 1882 & 1080 & 4601 & 1882 & 10842 \\
\hline 22 & 192 & 293 & 360 & 814 & 666 & 2164 & 1210 & 5521 & 2164 & 13553 \\
\hline 23 & 197 & 307 & 382 & 895 & 726 & 2489 & 1355 & 6625 & 2489 & 16941 \\
\hline 24 & 203 & 323 & 405 & 985 & 791 & 2863 & 1518 & 7950 & 2863 & 21176 \\
\hline 25 & 209 & 339 & 429 & $\begin{array}{l}108 \\
3\end{array}$ & 862 & 3292 & 1700 & 9540 & 3292 & 26470 \\
\hline 26 & 216 & 356 & 455 & $\begin{array}{l}119 \\
2\end{array}$ & 940 & 3786 & 1904 & 11448 & 3786 & 33087 \\
\hline 27 & 222 & 373 & 482 & $\begin{array}{l}131 \\
1\end{array}$ & $\begin{array}{l}102 \\
5\end{array}$ & 4354 & 2132 & 13737 & 4354 & 41359 \\
\hline 28 & 229 & 392 & 511 & $\begin{array}{l}144 \\
2\end{array}$ & $\begin{array}{l}111 \\
7\end{array}$ & 5007 & 2388 & 16484 & 5007 & 51699 \\
\hline 29 & 236 & 412 & 542 & $\begin{array}{l}158 \\
6 \\
\end{array}$ & $\begin{array}{l}121 \\
7\end{array}$ & 5758 & 2675 & 19781 & 5758 & 64623 \\
\hline 30 & 243 & 432 & 574 & 174 & 132 & 6621 & 2996 & 23738 & 6621 & 80779 \\
\hline
\end{tabular}




\begin{tabular}{|l|l|l|l|l|l|l|l|l|l|l|}
\hline & & & & 5 & 7 & & & & & \\
\hline 31 & 250 & 454 & 609 & 9 & 6 & 7614 & 3356 & 28485 & 7614 & 100974 \\
\hline
\end{tabular}

If the growth rate is $1 \%$ and $\mathrm{P}=5$, then the number of infected people will be doubled after 15 days, whereas, $\mathrm{R}=5$ and $\mathrm{P}=5$, then the number of infected people will be 244 after the 4 th day, 1,164 after 11th day, 10,842 after the 20th day and 1,00,974 after 31 st day. Thus the growth rate as well as the $\mathrm{P}$ value play a vital role in prevention of any types of epidemics.

\subsubsection{Complexity}

The Virus graph representation includes either adjacency matrix or adjacency list. The adjacency matrix is $2 \mathrm{D}$ matrix that has row and column combination. The combination may include growth rate and number of infected people. The complexity of representing this information will have $\mathrm{O}\left(\mathrm{n}^{2}\right)$. On the other side, if it is implemented using adjacency list, the complexity will be $\mathrm{O}(\mathrm{v}+\mathrm{e})$, where $\mathrm{v}$ is vertices and e is edges connecting those vertices.

\subsubsection{Limitations}

In this paper, the data under consideration is enormous and varying, consequently the size of virus graph is extremely large. The cut sets of the graphs recommended for the prevention of the COVID-19 is large but if handled logically, will award superior results. The growth rate is high, so practically difficult to measure, but mathematically it is simple to analyze.

\subsection{Conclusions and Future Outlook}

Mathematical modelling always plays very significant role in the smooth functioning of the world. The aim of this paper is to understand outbreak of COVID-19 using graph theory model. By applying different aspects of Mathematics, world's universal problems have had been consistently resolved. Concepts of graph theory have provided the mathematical modeling of the COVID-19. It has also been suggested methods to control the spread of some types of pandemic. Types of Virus graphs as well as growth rates are modeled by using graphs. Our analysis and study indicates that there is special need to identify minutiae of pandemic and apply astonishing theories for maintaining the smooth harmony of mankind. It 
seems that there is infinite scope of mathematics for the research as well as resolving social and technical problems of the world.

\section{References}

1. B. Zmazek and J. 'Zerovnik, Behzad -Vizing conjecture and Cartesian product graphs, Elect. Notes in Discrete Math. 17 (2004), 297-300.

2. D.B.West, An introduction to graph theory, Prentice- Hall, Pearson Edison India (1995).

3. Dave DeCapprio* Joseph Gartner et al, Building a COVID-19 Vulnerability Index, medRxiv preprint doi: https://doi.org/10.1101/2020.03.16.20036723.

4. F. R. K. Chung and L. Lu, Complex Graphs and Networks, CBMS Regional Conference Series in Mathematics, American Mathematical society, volume 107, (2006).

5. Giulia Giordano, G., Blanchini, F., Bruno, R., Colaneri, P., Di Filippo, A., Di Matteo, A., \& Colaneri, M. (2020). A SIDARTHE Model of COVID-19 Epidemic in Italy. arXiv preprint arXiv:2003.09861.

6. H. R. Bhapkar and J. N. Salunke, The Geometric Dual of HB Graph, *outerplanar Graph and Related Aspects, Bulletin of Mathematical Sciences and Applications, ISSN 2278-9634, Volume 3, No. 3, pp 114119, (2014), 114-119.

7. Ibrar ul Hassan Akhtar. "Understanding the CoVID-19 pandemic Curve through statistical approach", cold Spring Harbor Laboratory, 2020

8. J. A. Bondy and U. S. R. Murty, "Graph Theory with Applications". Elsevier, MaccMillan, New York - London, 1976.

9. Shinde, Gitanjali R;Kalamkar, Asmita B.; Mahalle, Parikshit N; Dey, Nilanjan; Chaki, Jyotismita; Hassanien, Aboul ella; . (2020): Forecasting Models for Coronavirus (COVID-19): A Survey of the State-of-theArt. TechRxiv. Preprint. https://doi.org/10.36227/techrxiv.12101547.v1

10. Mahalle, Parikshit.N.; Sable, Nilesh.P.; Mahalle, Namita.P.; Shinde, Gitanjali.R. Predictive Analytics of COVID-19 Using Information, Communication and Technologies. Preprints 2020, 2020040257 (doi: 10.20944/preprints202004.0257.v1).

11.Fong, S. J., Li, G., Dey, N., Crespo, R. G., \& Herrera-Viedma, E. (2020). Composite Monte Carlo decision making under high uncertainty of novel coronavirus epidemic using hybridized deep learning and fuzzy rule induction. Applied Soft Computing, 106282.

12.Fong, S. J., Li, G., Dey, N., Crespo, R. G., \& Herrera-Viedma, E. (2020). Finding an accurate early forecasting model from small dataset: 
A case of 2019-ncov novel coronavirus outbreak. arXiv preprint arXiv:2003.10776.

13.Hu, S., Liu, M., Fong, S., Song, W., Dey, N., \& Wong, R. (2018). Forecasting China future MNP by deep learning. In Behavior engineering and applications (pp. 169-210). Springer, Cham.

14.Rajinikanth, V., Dey, N., Raj, A. N. J., Hassanien, A. E., Santosh, K. C., \& Raja, N. (2020). Harmony-Search and Otsu based System for Coronavirus Disease (COVID-19) Detection using Lung CT Scan Images. arXiv preprint arXiv:2004.03431.

15.Kamal, M. S., Parvin, S., Ashour, A. S., Shi, F., \& Dey, N. (2017). DeBruijn graph with MapReduce framework towards metagenomic data classification. International Journal of Information Technology, 9(1), 59-75.

16. Narsingh Deo, Graph Theory with Applications to Engineering and Computer Science, Prentice -Hall of India,2003.

17. R. Frucht and F. Harary, On the corona of two graphs, Aequationes Math. 4 (1970), 322-325.

18. Simon James Fong1,2*, Gloria Li2, Nilanjan Dey at al, Composite Monte Carlo Decision Making under High Uncertainty of Novel Coronavirus Epidemic Using Hybridized Deep Learning and Fuzzy Rule Induction, Applied Soft Computing.

19. Volpert, V., Banerjee, M., \& Petrovskii, S. (2020). On a quarantine model of coronavirus infection and data analysis. Mathematical Modelling of Natural Phenomena,

20. Weber, A., Ianelli, F., \& Goncalves, S. (2020). Trend analysis of the COVID-19 pandemic in China and the rest of the world. arXiv preprint arXiv:2003.09032.

21. WHO. Novel Corona virus (2019-nCoV) Situation Report - 39. 2020 [cited 2020 April 20]; Available from: https://www.who.int/docs/defaultsource/coronaviruse/situationreports/2 0200228-sitrep-39-covid-19.pdf?sfvrsn=5bbf3e7d_2. 